\title{
Concept of brain transplant in pre-historic era
}

\author{
R. Kumar • A. K. Mahapatra
}

Published online: 28 October 2008

(C) Springer-Verlag 2008

In India, in the pre-historic period, great truths were revealed in the form of stories. More often, they were revealed in more subtle forms and needed a lot of meditative thinking with profound results when applied into real practice.

Lords Shiva is considered the supreme God in Hinduism. $\mathrm{He}$ is both static and dynamic and is both creator and destroyer of the universe. He has gentle as well as fierce forms. He is the destroyer of evil and protects good. It appears that Lord Shiva had the concept of not only the functional anatomy of brain and CSF flow within the brain but the concept of brain transplantation as well [1].

It is known that earlier Lord Shiva had already performed transplantation of head in his own son after beheading his own son Lord Ganesha in a fit of anger when he disobeyed his command [2].

But this was not the only time that he has been referred to have performed transplantation of head. There is one more instance in a Hindu scripture known as "Vaman Purana" where the Lord Shiva danced the dance of death and destruction (Tandav Nratya) in order to destroy Yajna (sacrificial ritual, which took an animated form in wake of the Lord Shiva's attack).

The incident goes like this; Lord Shiva's wife, Sati (Shakti, the power) once went uninvited to attend the ceremony of Yajna at her father's (Daksh Prajapati) place. There, her father used derogatory words on her and her husband (Lord Shiva) for coming alone and uninvited. She, then, out of anger and dejection, committed suicide by

R. Kumar $(\bowtie) \cdot$ A. K. Mahapatra

Department of Neurosurgery, Sanjay Gandhi Post Graduate Institute of Medical Sciences,

Lucknow, 226014 Uttar Pradesh, India

e-mail: rajkumar1959@gmail.com jumping into the ongoing divine fire (Yajna). When Lord Shiva heard of this incident, he himself went to Daksh's place and performed once again the dance of death and destruction. He then beheaded Daksh (his father-in-law), who had inadvertently managed to earn his wrath.

When his anger subsided, an army of his followers and devotees tried to persuade Lord Shiva to perform head

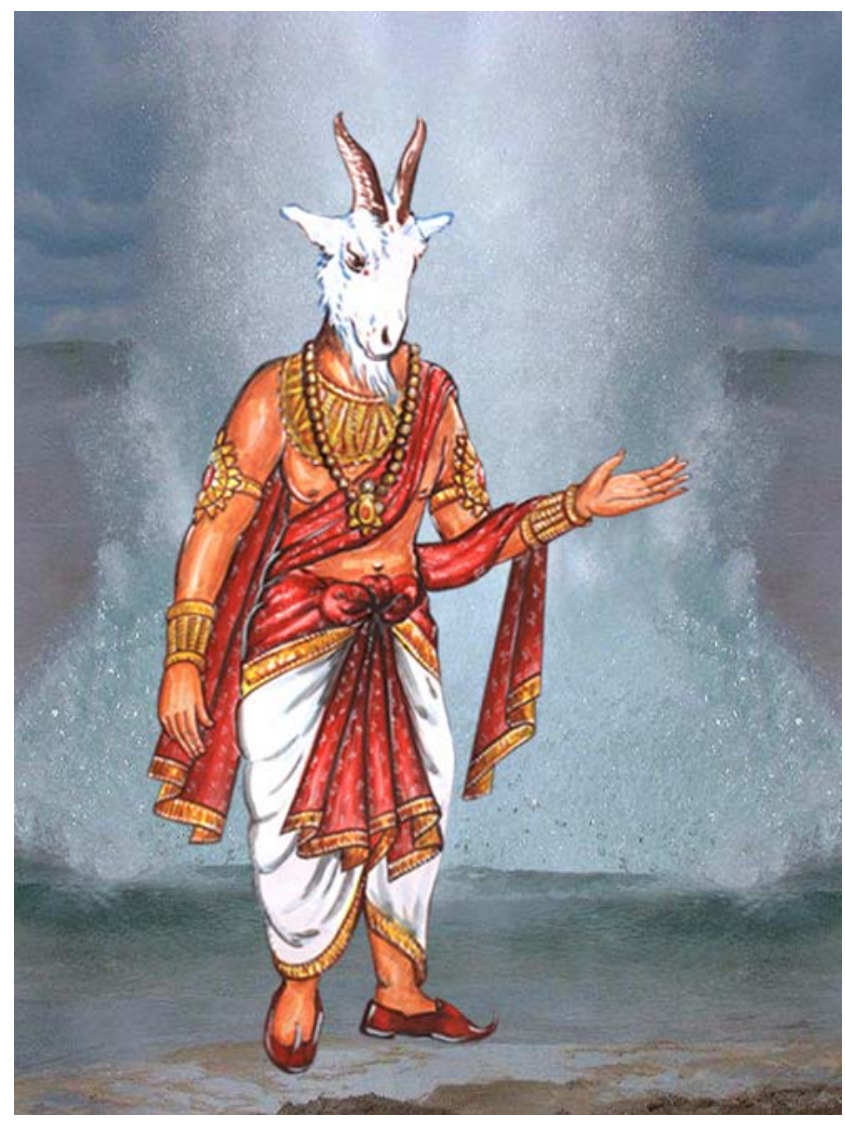

Fig. 1 Daksh Prajapati 
transplantation on his father-in-law. Now, goats were readily available at the site of the sacrificial ritual as they were frequently used as sacrificial animals and the time was short so Lord Shiva immediately decided to transplant a head of a goat onto his father-in-law's body. He immediately called up on his other team members to assist him in transplanting the head of a goat on the beheaded Daksh Prajapati [3] (Fig. 1).

\section{References}

1. Kumar R, Gupta D (2006) Shiva: supreme God of all in Saivism. Child Nerv Syst 22(12):1511

2. Kumar R, Kalra SK, Mahapatra AK (2008) Lord Ganesha: the idol neurosurgeon. Childs Nerv Syst 24:287-288

3. Charak KS Introduction of Medical Astrology in Book of Essentials of Medical Astrology, chapter 1, by Vedic Astrology pp 2-5 